\title{
PERAN SERTA PEMANGKU KEPENTINGAN DALAM PENGELOLAAN JARINGAN IRIGASI PADA DAERAH IRIGASI TIYINGTALI DI KABUPATEN BULELENG
}

\author{
Ni Made Agia Dwita Utami ${ }^{1}$, Krisna Kurniari ${ }^{2}$, Kadek Diana Harmayani ${ }^{3}$, Gusti \\ Ayu Putu Candra Dhamayanti ${ }^{4}$ \\ ${ }^{1,3,4}$ Program Studi Teknik Sipil Universitas Udayana \\ ${ }^{2}$ Program Studi Teknik Sipil Universitas Mahasaraswati Denpasar \\ Email: ghie.only@gmail.com
}

doi: https://doi.org/10.24843/SPEKTRAN.2021.v09.i01.p07

\begin{abstract}
ABSTRAK
Keberhasilan sektor pertanian tidak terlepas dari manajemen pengelolaan sistem jaringan irigasi dan peran serta pemangku kepentingan yaitu pemerintah dan pengelola subak. Sampai saat ini masih banyak permasalahan yang dialami dalam pengelolaan jaringan irigasi akibat kurang optimalnya peran serta pemangku kepentingan, lambatnya respon penanganan terhadap masalah pengelolaan jaringan irigasi sehingga berdampak pada tidak meratanya pembagian air dari saluran tersier ke areal pertanian. Hal ini juga terjadi pada Daerah Irigasi (DI) Tiyingtali yang mengalami permasalahan jaringan irigasi seperti terjadinya sedimentasi pada saluran sekunder yang mengakibatkan besarnya volume pelimpahan air saat musim hujan, serta kurang optimalnya pembagian air dari hulu ke hilir. Sehingga penelitian ini bertujuan untuk menganalisis peran serta pemangku kepentingan dalam pengelolaan jaringan irigasi pada DI Tiyingtali. Pendekatan yang digunakan dalam penelitan adalah dengan pendekatan eksploratif dan metode deskritif analitis. Pengumpulan data dilakukan menggunakan kuisioner dan wawancara. Teknik pengambilan sampel/responden pada penelitian ini menggunakan metode purposive sampling, yaitu responden yang menangani pengelolaan jaringan irigasi di DI Tiyingtali yang mecakup pemerintah 25 responden dan pengelola subak 33 responden. Analisis data dilakukan menggunakan regresi linear untuk menganalisis pengaruh peran serta pemangku kepentingan terhadap pengelolaan jaringan irigasi. Selanjutnya dilakukan analisis deskriptif dari hasil wawancara untuk merumuskan upaya peningkatan kinerja dan peran serta pemangku kepentingan. Hasil penelitian menunjukkan pemangku kepentingan berperan sebesar $68,3 \%$ dalam pengelolaan jaringan irigasi, sedangkan 31,7\% sisanya dipengaruhi oleh faktor lainnya. Pemangku kepentingan secara bersama-sama berpengaruh signifikan secara simultan dan secara parsial terhadap pengelolaan jaringan irigasi artinya peningkatan peran serta pemangku kepentingan secara simultan maupun parsial akan meningkatkan kegiatan pengelolaan jaringan irigasi.
\end{abstract}

Kata kunci: Peran serta Pemangku Kepentingan, Pengelolaan jaringan irigasi.

\section{PARTICIPATION OF STAKEHOLDERS IN THE IRRIGATION NETWORKS MANAGEMENT OF TIYINGTALI IRRIGATION AREA IN BULELENG DISTRICT}

\begin{abstract}
The success of agricultural sector cannot separated from the irrigation network system management and the stakeholder participation, the government and Subak organizer. Until now, there are still many problems experienced in irrigation networks management due to the lack of stakeholder participation, the slow response to handling problems in irrigation network management, resulting in unequal distribution of water from tertiary channels to agricultural areas. This also occurred in the Tiyingtali Irrigation Area (DI Tiyingtali), which experienced problems with irrigation networks such as sedimentation in secondary channels that makes a large volumes of water overflow during the rainy season, and lack of water distributions. This study has a pupose to analyze stakeholders participation of the irrigation networks management in DI Tiyingtali. The approach used in this research is an exploratory approach and analytical descriptive methods. Data collection was carried out using questionnaires and interviews. The sampling technique/respondent in this study used a purposive sampling method, who handled the management of the irrigation network in DI Tiyingtali which included of 25 respondents government and 33 respondents from subak organizer. Data analysis was performed using linear regression to analyze the influence of stakeholder participation on irrigation network management. Descriptive from the interviews was conducted to formulate efforts to improve performance and the participation of stakeholders. The results showed that the stakeholders played $68.3 \%$ role in irrigation network management, while the remaining $31.7 \%$ was influenced by other factors. Stakeholders jointly have a significant effect
\end{abstract}


simultaneously and partially on irrigation network management, that means the increased participation of stakeholders simultaneously or partially will increase irrigation network management activities.

Keywords: Participation of Stakeholders, Management of irrigation networks.

\section{PENDAHULUAN}

Peran serta pemangku kepentingan dalam hal ini pemerintah maupun subak memiliki peranan penting dalam menunjang keberhasilan manajemen pengelolaan jaringan irigasi. Rencana dan pengambilan keputusan pada suatu daerah irigasi berawal dari usulan masyarakat petani pemakai air atau subak yang kemudian usulan tersebut disampaikan kepada instansi terkait untuk ditindaklanjuti. Namun kenyataannya, masih banyak permasalahan yang dialami dalam pengelolaan jaringan irigasi akibat kurang optimalnya peran serta atau partisipasi stakeholders.

Salah satu jaringan irigasi yang memiliki masalah adalah jaringan irigasi Tiyingtali pada Daerah Irigasi Tiyingtali. Berdasarkan Keputusan Menteri Pekerjaan Umum Nomor : 293/KPTS/M/2014 tentang Penetapan Status Daerah Irigasi Tiyingtali yang pengelolaannya menjadi wewenang dan tanggung jawab Pemerintah Pusat, Pemerintah Provinsi dan Pemerintah Kabupaten/Kota, status Daerah Irigasi Tiyingtali menjadi wewenang dan tanggung jawab Pemerintah Provinsi Bali yang terletak di Kabupaten Buleleng.

Berdasarkan laporan akhir tahun 2018 seksi pelaksanaan sumber daya air Dinas Pekerjaan Umum dan Penataan Ruang Provinsi Bali untuk kegiatan rehabilitasi dan peningkatan jaringan irigasi, daerah irigasi Tiyingtali sampai saat ini masih memiliki saluran irigasi yang belum terbangun. Saluran irigasi pada jaringan irigasi Tiyingtali masih belum sepenuhnya dapat ditangani oleh Pemerintah maupun Subak. Berdasarkan laporan pengamat daerah irigasi Tiyingtali masih ada bangunan irigasi yang rusak di beberapa titik pada jaringan irigasi tersebut. Bangunan irigasi yang rusak tersebut menyebabkan kebocoran pada beberapa saluran irigasi. Selain itu saluran irigasi yang belum dibangun di beberapa titik masih terbuat dari tanah sehingga terjadinya kehilangan air akibat resapan.

Permasalahan-permasalahan yang muncul tersebut mengindikasikan kurangnya peran serta pemangku kepentingan dalam pengelolaan jaringan irigasi, baik itu dalam operasi dan pemeliharaan, serta rehabilitasi jaringan irigasi pada daerah irigasi Tiyingtali. Peran serta pemangku kepentingan dalam hal ini antara Pemerintah dan pengurus Subak harus berjalan secara harmonis, sehingga pengelolaan jaringan irigasi Tiyingtali dapat terlaksana secara efektif, efisien dan berkelanjutan. Mengingat pentingnya peran serta pemangku kepentingan dalam pengelolaan jaringan irigasi agar dapat berjalan secara optimal, maka dari itu perlu diidentifikasi lebih lanjut bagaimana peran serta pemangku kepentingan dalam pengelolaan jaringan irigasi pada Daerah Irigasi Tiyingtali di Kabupaten Buleleng.

Berdasarkan latar belakang yang telah diuraikan diatas ada rumusan masalah yang dapat diuraikan adalah bagaimana peran serta pemangku kepentingan dalam pengelolaan jaringan irigasi pada Daerah Irigasi Tiyingtali di Kab. Buleleng. Sejalan dengan rumusan masalah yang telah dikemukakan di atas tujuan dari penelitian ini adalah untuk menganalisis peran serta pemangku kepentingan dalam pengelolaan jaringan irigasi pada Daerah Irigasi Tiyingtali Kab Buleleng.

\section{IRIGASI}

Pengertian irigasi yang tercantum dalam Peraturan Menteri Pekerjaan Umum No. 30/PRT/M/2015 adalah usaha penyediaan, pengaturan, dan pembuangan air irigasi untuk menunjang pertanian yang jenisnya meliputi irigasi permukaan, irigasi rawa, irigasi air bawah tanah, irigasi pompa, dan irigasi tambak.Bangunan irigasi diperlukan untuk menunjang pengambilan dan pengaturan air. Beberapa jenis bangunan irigasi yang sering dijumpai dalam praktek irigasi antara lain (Standar Perencanaan Bagian Irigasi KP - 01): bangunan utama, bangunan pembawa, bangunan bagi dan sadap, bangunan pengukur dan pengatur, bangunan pengatur muka air, bangunan pembuang dan penguras, bangunan pelengkap dan bangunan lindung. Sedangkan jaringan irigasi menurut Peraturan Menteri Pekerjaan Umum No. 14/PRT/M/2015 adalah saluran, bangunan, dan bangunan pelengkapnya yang merupakan satu kesatuan yang diperlukan untuk penyediaan, pembagian, pemberian, penggunaan, dan pembuangan air irigasi. Ketentuan yang mengatur tentang jaringan irigasi di Indonesia dituangkan dalam Kriteria Perencanaan Bagian Jaringan Irigasi KP.01 Departemen Pekerjaan Umum Direktorat Jenderal Pengairan tahun 1986. Pada buku tersebut diuraikan bahwa suatu jaringan irigasi umumnya memiliki empat (4) unsur fungsional pokok, yaitu: pertama bangunan-bangunan utama (headwork) dimana air diambil dari sumbernya yang umumnya dari sungai atau waduk, kedua adalah jaringan pembawa berupa saluran dengan bangunan-bangunan yang mengalirkan air irigasi ke petak-petak tersier, ke tiga adalah petak-petak tersier dengan sistem pembagian air dan sistem pembuangan kolektif dimana air irigasi dibagi dan dialirkan ke petak-petak sawah dan kelebihannya ditampung dalam suatu sistem pembuangan didalam petak tersier, dan yang terakhir yakni yang ke empat 
adalah sistem pembuangan yang ada di luar daerah irigasi untuk membuang kelebihan air irigasi ke sungai atau saluran-saluran alamiah lainnya.

\section{Irigasi Subak}

Pada peraturan Peraturan Daerah Provinsi Bali Nomor 9 Tahun 2012 subak di definisikan sebagai organisasi tradisional yang membidangi tata guna air atau tata guna tanaman pada usaha pertanian di masyarakat adat. Dalam sistem irigasi subak, yang ditekankan adalah keadilan dalam memperoleh air. Apabila air yang mengalir tidak cukup untuk mengairi seluruh areal sawah maka pemberian air dilakukan dengan cara pergiliran atau rotasi, yaitu subak dibagi menjadi bagian yang lebih kecil yang disebut dengan tempek. Subak melakukan musyawarah atau sangkepan dalam melaksanakan pengelolaan operasi serta pemeliharaan.

Subak sebagai organisasi yang fungsi utamanya adalah mengatur air irigasi telah membangun sistem jaringan irigasi dengan keunggulan teknologi tradisionalnya, dimana kostruksi jaringan sangat disesuaikan oleh kondisi fisik alam dimana jaringan itu dikronstruksi. Ketika subak membangun jaringan irigasinya banyak memanfaatkan alur alam berupa lembah atau pangkung sebagai saluran pembawa

Secara prinsip antara jaringan irigasi dengan jaringan irigasi subak memiliki tugas dan kewajiban yang sama. Sehingga dalam penelitian kali ini yang dimaksud dengan jaringan irigasi adalah jaringan irigasi subak. Jaringan irigasi subak sudah dibangun sedemikian lengkap mulai dari bangunan pengambilan pada sumber air, bangunan pembagi dan pengambilan di saluran sampai saluran distribusi di petak-petak sawah

\section{Pengelolaan jaringan irigasi}

Berdasarkan Peraturan Menteri Pekerjaan Umum No. 14/PRT/M/2015 pengelolaan jaringan irigasi meliputi kegiatan operasi serta pemeliharaan dan rehabilitasi. Pengelolaan jaringan irigasi primer dan sekunder dikelola oleh pemerintah provinsi, sedangkan jaringan irigasi tersier dikelola oleh subak.. Subak dapat berperan serta dalam pengelolaan jaringan irigasi primer dan sekunder sesuai dengan kebutuhan dan kemampuannya. Pengelolaan jaringan irigasi tersier menjadi hak dan tanggung jawab subak. Apabila subak tidak mampu bertanggung jawab terhadap pelaksanaan tersebut maka akan dibantu oleh pemerintah pusat, pemerintah provinsi, atau pemerintah kabupaten/kota dengan memberi bantuan dan atau dukungan fasilitas berdasarkan permintaan subak dengan memperhatikan prinsip kemandirian.

\section{PEMANGKU KEPENTINGAN}

Yang dimaksud dengan pemangku kepentingan adalah semua pihak yang mempengaruhi, dan atau dipengaruhi kebijakan, keputusan, dan tindakan sistem. Penggunan istilah "semua", itu berarti bahwa pemangku kepentingan tersebut dapat bersifat individual, masyarakat, kelompok sosial atau institusi dalam berbagai ukuran, kesatuan atau tingkat dalam masyarakat.

Berdasarkan Permen PU No. 30/PRT/M/2015 tentang Pengembangan dan Pengelolaan Sistem Irigasi, penanggung jawab kegiatan pengelolaan jaringan irigasi adalah pemerintah pusat, pemerintah daerah provinsi, pemerintah daerah kabupaten/kota, badan usaha, badan sosial, kelompok masyarakat, atau perseorangan yang melaksanakan pembangunan, peningkatan, operasi, pemeliharaan atau rehabilitasi jaringan irigasi di suatu wilayah tertentu.

Pemerintah selaku pemangku kepentingan dalam pengelolaan jaringan irigasi terkait dengan operasi dan pemeliharaan jaringan irigasi mencakup Direktorat Jenderal Sumber Daya Air - Kementrian Pekerjaan Umum, Pemerintah Provinsi, serta Pemerintah Kabupaten/Kota yang membidangi irigasi. Masyarakat umum yang merupakan pemangku kepentingan dalam pengelolaan jaringan irigasi Tiyingtali pada Daerah Irigasi Tiyingtali di Kabupaten Buleleng adalah masyarakat yang berkepentingan dalam penggunaan air yang bersumber dari DI. Tiyingtali melalui Jaringan Irigasi Tiyingtali yang digunakan untuk keperluan pertanian. Masyarakat yang dimaksud disini adalah Subak.

\section{PERAN SERTA PEMANGKU KEPENTINGAN}

Dapat diartikan bahwa partisipasi merupakan keterlibatan seseorang secara langsung dan spontanitas untuk turut serta dalam aktifitas karena adanya rasa memiliki, yang diterapkan dalam tahapan proses pembangunan dalam rangka pencapaian target tertentu. Macam partisipasi yaitu partisipasi dalam proses perencanaan/pembuatan keputusan (participation in decision making), partisipasi dalam pelaksanaan (participation in implementing), partisipasi dalam pemanfaatan hasil, dan partisipasi dalam evaluasi (participation in benefits). 
Berdasarkan Peraturan Menteri Pekerjaan Umum dan Perumahan Rakyat Nomor 14/PRT/M/2015 dijelaskan disana tentang wewenang dan tanggung jawab Pemerintah dan Pemerintah Daerah dengan ketentuan : daerah irigasi dengan luas diatas 3000 ha menjadi wewenang dan tanggung jawab pemerintah pusat, daerah irigasi antara 1000 ha - 3000 ha menjadi kewenangan pemerintah provinsi dan daerah irigasi lebih kecil dari 1000 ha sepenuhnya menjadi kewenangan dan tanggung jawab pemerintah kabupaten, sedangkan jika berada pada lintas kabupaten maka menjadi tanggung jawab organisasi petani dalam hal ini adalah subak. Peraturan tersebut juga menjelaskan bahwa pengelolaan jaringan irigasi adalah kegiatan yang meliputi operasi, pemeliharaan, dan rehabilitasi jaringan irigasi di daerah irigasi. Maka dari itu operasi dan pemeliharaan termasuk dalam pengelolaan jaringan irigasi.

Menurut Peraturan Menteri Pekerjaan Umum dan Perumahan Rakyat Nomor 30/PRT/M/2015 secara umum dijabarkan masyarakat petani/P3A/GP3A/IP3 dapat berperan serta dalam pelaksanaan uji pengaliran dan penyesuaian manual operasi dan pemeliharaan jaringan irigasi yang didasarkan pada hasil uji pengaliran dengan cara mengamati dan melaporkan kejadian pada jaringan irigasi, seperti terjadinya kebocoran, longsor, banjir dan limpasan selama uji pengaliran berlangsung kepada penanggung jawab kegiatan. Masyarakat petani/P3A/GP3A/IP3 dalam hal ini adalah Subak.

\section{METODE}

Pendekatan yang digunakan dalam penelitan adalah dengan pendekatan eksploratif dan metode deskritif analitis. Pengumpulan data dilakukan menggunakan kuisioner dan wawancara. Teknik pengumpulan sampel pada penelitian peran serta pemangku kepantingan dalam pengelolaan jaringan irigasi Daerah Irigasi Tiyingtali di Kabupaten Buleleng menggunakan metode purposive sampling. Responden yang digunakan dalam penelitian ini adalah 58 responden dimana 25 responden dari unsur pemerintah, dan 33 responden dari masyarakat (Subak). Analisis data dilakukan secara deskristif kualitatif dengan analisis menggunakan skala likert yang digunakan untuk mengukur sikap, pendapat dan persepsi pemangku kepentingan dalam pengelolaan jaringan irigasi.

\section{HASIL DAN PEMBAHASAN}

Penelitian dilakukan pada jaringan irigasi tersier pada Daerah Irigasi Tiyingtali di Kabupaten Buleleng. Subak yang akan diteliti dalam penelitian ini berjumlah 16 Subak yang dimana masing-masing subak tersebut juga memiliki saluran tersier. Adapun subak tersebut dapat dilihat pada Tabel 1. di bawah ini.

Tabel 1. Data Subak pada Daerah Irigasi Tiyingtali.

\begin{tabular}{clcc}
\hline \multirow{2}{*}{ No } & \multirow{2}{*}{ Nama Subak } & Baku & Fungsional \\
\cline { 3 - 4 } & & 131,89 & 117,09 \\
\hline 1 & Sambangan & 102,05 & 100,73 \\
\hline 2 & Kedu & 25,70 & 25,70 \\
\hline 3 & Mandul & 46,30 & 46,30 \\
\hline 4 & Lobong & 135,00 & 135,00 \\
\hline 5 & Umapanji & 102,00 & 100,75 \\
\hline 6 & Bedangin & 25,00 & 25,00 \\
\hline 7 & Bab. Dauh Sema & 5,00 & 5,00 \\
\hline 8 & Tegal Panji & 95,80 & 95,80 \\
\hline 9 & Dauh Sema & 68,00 & 68,00 \\
\hline 10 & Bangah & 44,00 & 44,00 \\
\hline 11 & Dauh Bunut & 27,15 & 27,15 \\
\hline 12 & Cempaka & 90,68 & 90,68 \\
\hline 13 & Lapang Bedauh & 87,31 & 87,31 \\
\hline 14 & Batupulu Bawah & 50,00 & 50,00 \\
\hline 15 & Batupulu Atas & 145,60 & 145,60 \\
\hline 16 & Pancoran & &
\end{tabular}

a. $\quad$ Uji Validitas dan Reabilitas

Untuk mengetahui tingkat peran serta pemangku kepentingan dalam pengelolaan jaringan irigasi tersier pada Daerah irigasi Tiyingtali di Kabupaten Buleleng diperlukan suatu data yang harus diuji tingkat 
validitas dan reliabilitasnya. Agar data dan informasi yang diperlukan dalam penelitian dikatakan valid harus memiliki tingkat akurasi yang dapat dipercaya dan memiliki tingkat kebenaran yang mewakili representasi komunitas pemangku kepentingan. Kuisoner yang telah disebarkan diuji menggunakan aplikasi SPSS Versi 25.0 untuk mendapatkan tingkat validitas dan realibilitas dari kuisioner tersebut.

Uji validitas diperlukan untuk mengetahui kevalidan item pertanyaan yang digunakan. Dalam penelitian ini validitas dapat dijelaskan sebagai suatu derajat ketepatan alat ukur penelitian tentang inti atau arti sebenarnya yang diukur. Tinggi rendahnya validitas menunjukan sejauh mana data yang terkumpul tidak menyimpang dari gambaran tentang variable yang dimaksud. Hasil uji validitas disajikan dalam Tabel 2 di bawah ini.

Tabel 2 Hasil Uji Validitas

\begin{tabular}{clcc}
\hline No. & \multicolumn{1}{c}{ Variabel } & Koefisien Korelasi & Keterangan \\
\hline 1. & Peran Serta Pemerintah & $0,404-0,884$ & Valid \\
\hline 2. & Peran Serta Subak & $0,578-0,810$ & Valid \\
\hline 3. & Pengelolaan Jaringan Irigasi & $0,656-0,822$ & Valid \\
\hline
\end{tabular}

Berdasarkan tabel diatas dapat dilihat bahwa seluruh butir pertanyaan atau pernyataan dalam penelitian ini telah memiliki koefisien korelasi $r_{\text {hitung }}>r_{\text {table }}$, dimana $r_{\text {table }}$ untuk $N=58$ adalah 0,2542. Jadi dapat disimpulkan bahwa seluruh butir pertanyaan atau pernyataan dalam instrumen penelitian ini telah memenuhi syarat validitas data.

Reliabilitas adalah derajat ketepatan, ketelitian atau keakuratan yang ditunjukkan ole instrument pengukuran. Data yang reliable diperoleh dari hasil pengukuran suatu alat yang mampu menunjukkan adanya konsistensi atas hasil-hasilnya ketika mengukur gejala yang sama. Suatu instrument yang reliabel adalah data pada instrument tersebut memiliki nilai Cronbach Alpha >0,6. Hasil uji reliabilitas disajikan dalam Tabel 3 di bawah ini.

Tabel 3 Hasil Uji Reliabilitas

\begin{tabular}{clcc}
\hline No. & \multicolumn{1}{c}{ Variabel } & Cronbach Alpha & Keterangan \\
\hline 1. & Peran Serta Pemerintah & 0,906 & Valid \\
\hline 2. & Peran Serta Subak & 0,845 & Valid \\
\hline 3. & Pengelolaan Jaringan Irigasi & 0,970 & Valid \\
\hline
\end{tabular}

Berdasarkan tabel diatas dapat dilihat bahwa seluruh variable uji dalam penelitian ini memiliki nilai Cronbach Alpha > 0,6. Sehingga dapat disimpulkan bahwa seluruh variable telah memenuhi asumsi reliabilitas data.

\section{b. Uji Pengaruh Variabel}

Hasil uji pengaruh secara simultan (Uji F) menunjukkan nilai $\mathrm{F}_{\text {hitung }}(10,961)>\mathrm{F}_{\text {tabel }}(3,26)$ maka $\mathrm{H}_{0}$ ditolak dengan $\mathrm{H}_{1}$ diterima. Hal ini menunjukkan bahwa pemangku kepentingan baik itu Pemerintah dan Subak berperan serta secara bersama-sama atau simultan dan signifikan dalam pengelolaan jaringan irigasi pada Daerah Irigasi Tiyingtali di Kabupaten Buleleng.

Gambar 1. Daerah pengujian penerimaan/penolakan $\mathrm{H}_{0}$ dengan uji $\mathrm{F}$ untuk peran serta pemangku kepentingan

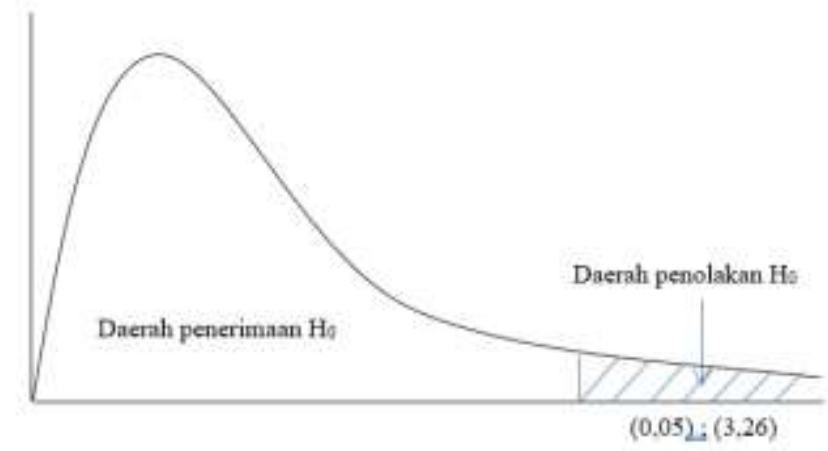


Hasil uji pengaruh secara parsial (uji t) untuk peran serta pemerintah menunjukkan nilai $t_{\text {hitung }}$ $(1,924)>t_{\text {tabel }}(1,673)$. Hal ini menunjukkan bahwa pemerintah berperan serta positif dan signifikan dalam pengelolaan jaringan irigasi pada Daerah Irigasi Tiyingtali di Kabupaten Buleleng.

Gambar 2. Daerah pengujin penerimaan/penolakan $\mathrm{H}_{0}$ dengan uji $\mathrm{t}$ untuk peran serta pemerintah

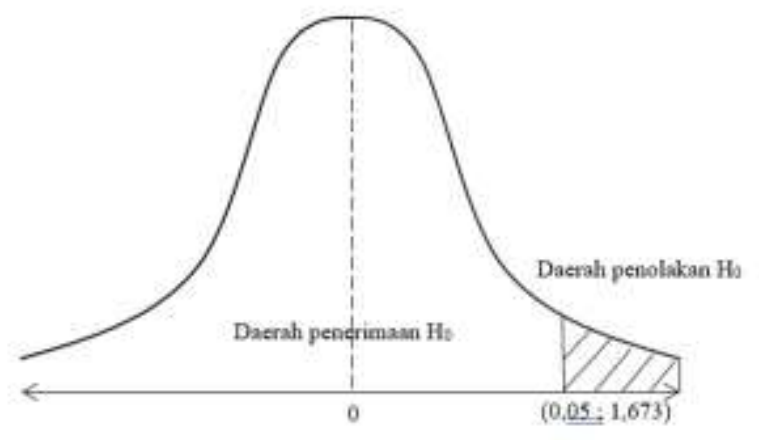

Hasil uji pengaruh secara parsial (uji t) untuk peran serta Subak menunjukkan nilai $t_{\text {hitung }}(4,029)>$ $\mathrm{t}_{\text {tabel }}(1,673)$. Hal ini menunjukkan bahwa Subak berperan serta positif dan signifikan dalam pengelolaan jaringan irigasi pada Daerah Irigasi Tiyingtali di Kabupaten Buleleng.

Gambar 3. Daerah pengujian penerimaan/penolakan $\mathrm{H}_{0}$ dengan uji t untuk peran serta Subak

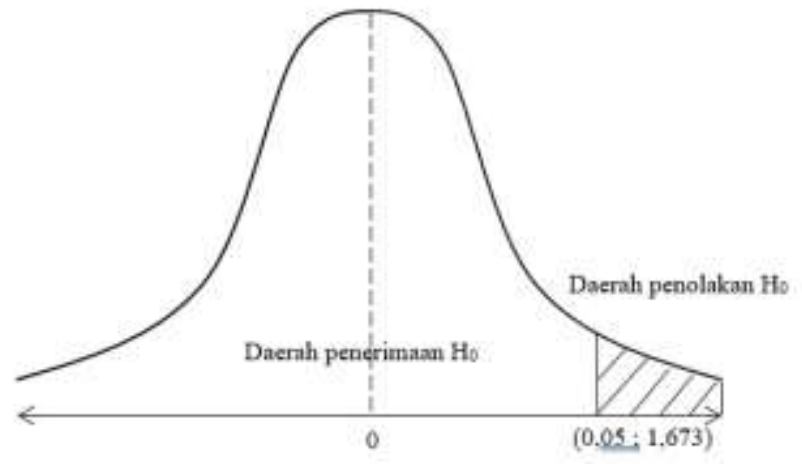

c. Peran Serta Pemangku Kepentingan

Besaran peran serta pemangku kepentingan dalam pengelolaan jaringan irigasi pada Daerah Irigasi Tiyingtali di Kabupaten Buleleng diukur dengan menggunakan nilai adjust $R$ square. Berdasarkan Analisa menggunakan SPSS 25.0 di dapatkan nilai adjust $R$ square sebesar 0,683. Nilai tersebut menunjukkan bahwa pemangku kepentingan (pemerintah dan Subak) berperan sebesar 68,3\% dalam pengelolaan jaringan irigasi pada Daerah Irigasi Tiyingtali di Kabupaten Buleleng, sedangkan 31,7\% sisanya dipengaruhi oleh faktor lainnya yang tidak termasuk dalam pembahasan penelitian.

Peran dominan dari masing-masing pemangku kepentingan diukur dengan analisis standarized coefficient beta. Analisis ini digunakan untuk mengetahui pengaruh variabel dominan dari pemangku kepentingan dalam pengelolaan jaringan irigasi pada Daerah Irigasi Tiyingtali di Kabupaten Buleleng. Adapun hasil analisanya disajikan pada Tabel 4 di bawah ini.

Tabel 4 Hasil analisis standardized coefficient beta.

\begin{tabular}{lcc}
\hline \multicolumn{1}{c}{ Variabel } & Standardized Coefficient Beta & Tingkat Peran Serta \\
\hline Peran Serta Pemerintah & 0,109 & II \\
\hline Peran Serta Subak & 0,496 & I \\
\hline
\end{tabular}

Berdasarkan tabel diatas diketahui bahwa variabel bebas dengan nilai absolut standardized coefficient beta tertinggi adalah peran serta Subak. Jadi peran serta Subak merupakan variabel yang dominan berpengaruh terhadap pengelolaan jaringan irigasi pada Daerah Irigasi Tiyingtali di Kabupaten Buleleng dibandingkan dengan peran serta pemerintah. 


\section{i. $\quad$ Peran Serta Pemerintah}

Dari hasil analisa yang telah dilakukan dapat diketahui bahwa peran serta pemerintah berpengaruh secara signifikan baik secara simultan maupun parsial terhadap kegiatan pengelolaan jaringan irigasi pada Daerah Irigasi Tiyingtali di Kabupaten Buleleng. Dari hasil analisa dalam ujii F yang dilakukan dapat diketahui bahwa $\mathrm{F}_{\text {hitung }}=10,961$ dan nilai $\mathrm{F}_{\text {tabel }}$ dengan tingkat keyakinan $95 \%$ dan $\alpha=0,05$ derajat bebas $(\mathrm{df})=(\mathrm{k}-1) ;(\mathrm{n}-\mathrm{k})=(2 ; 55)$ adalah sebesar 3,26. Oleh karena $F_{\text {hitung }}$ lebih besar daripada $F_{\text {tabel }}$ dengan nilai signifikasi $0,000<0,05$ maka variabel peran serta Pemerintah dan peran serta Subak secara bersama-sama berpengaruh secara simultan dan signifikan terhadap pengelolaan jaringan irigasi pada Daerah Irigasi Tiyingtali di Kabupaten Buleleng. Untuk hasil uji t didapat nilai thitung $(1,924)>$ ttabel $(1,673)$. Hal ini menunjukkan bahwa Pemerintah berperan serta positif dan signifikan dalam pengelolaan jaringan irigasi pada Daerah Irigasi Tiyingtali di Kabupaten Buleleng.

Berdasarkan hasil analisa tingkat peran serta pemerintah menunjukkan nilai Standardized Coefficient Beta sebesar 0,109 masih lebih kecil dari tingkat peran serta Subak. Hal ini menunjukkan bahwa responden menilai pemerintah kurang berperan serta dalam pengelolaan jaringan irigasi pada Daerah Irigasi Tiyingtali di Kabupaten Buleleng. Sehingga diperlukannya peningkatan peran serta oleh pemerintah agar pengelolaan jaringan irigasi tersebut dapat lebih optimal.

Pemerintah memilik peran yang sangat penting dalam kegiatan pengelolaan jaringan irgasi. Pengelolaan jaringan irigasi merupakan kegiatan yang meliputi operasi jaringan irigasi, pemeliharaan jaringan irigasi dan rehabilitasi jaringan irigasi pada Daerah Irigasi. Pemerintah berperan serta dalam kegiatan pengumpulan data seperti pengumpulan data debit, data curah hujan, data luas tanam, serta pembuatan laporan pengoperasian bangunan irigasi.

Dalam kegiatan perencanaan pengelolaan jaringan irigasi pemerintah berpartisipasi rutin dalam membuat rencana penyediaan air tahunan, pembagian dan pemberian air tahunan, rencana tata tanam tahunan, rencana pengeringan, berperan sebagai pembimbing atau penasehat yang memberi masukan dan pertimbangan berkaitan dengan ketersediaan air yang mungkin bisa dipergunakan untuk pertanian.

Dalam kegiatan pelaksanaan pengelolaan jaringan irigasi pemerintah berpartisipasi dalam melaksanakan pembangunan saluran pada jaringan irigasi serta pembagian dan pemberian air dengan cara mengoperasikan bangunan irigasi, termasuk di dalamnya melaksanakan pengaturan pintu penguras bendung terhadap banjir yang datang, membuka/menutup pintu pengambilan utama, sesuai debit dan jadwal yang direncanakan, dan mengatur pintu kantong lumpur untuk menguras endapan lumpur. Pemerintah juga melaksanakan kegiatan monitoring dan evaluasi kegiatan pengelolaan jaringan irigasi pemerintah berpartisipasi dalam membuat laporan operasi seperti misalnya, pengumpulan data tanaman dan kerusakan tanaman, serta melaporkan jika terjadi kekurangan air yang kritis.

Berdasarkan hasil pengambilan data melalui kuisioner untuk indikator pengumpulan data, perencanaan pengelolaan jaringan irigasi serta pelaksanaan pengelolaan jaringan irigasi sebagian besar responden menyatakan pemerintah telah ikut berperan serta dengan baik. Namun tidak sedikit juga responden yang mengharapkan peningkatan peran serta pemerintah khususnya dalam kegiatan monitoring dan evaluasi dalam pengelolaan jaringan irigasi. Berdasarkan hasil wawancara dengan responden pemerintah kurang aktif dalam melakukan pendataan atas bangunan-bangunan irigasi yang kurang berfungsi dengan baik akibat adanya kerusakan dan kebocoran dibeberapa titik sehingga pemerintah diharapkan dapat segera melakukan perbaikan pada bangunan air yang rusak tersebut.

Dalam kegiatan pemeliharaan jaringan irigasi seperti pengamanan dan pencegahan kerusakan jaringan irigasi serta pemeliharan baik itu pemeliharaan rutin, pemeliharaan berkala, maupun perbaikan kerusakan akibat bencana alam sebagian besar responden menyatakan pemerintah sudah turut berperan serta. Namun tidak sedikit juga yang tidak setuju mengenai hal tersebut. Berdasarkan wawancara dengan responden, keterbatasan dana menjadikan kurang optimalnya peran serta pemerintah dalam pemeliharaan, pengamanan serta pencegahan kerusakan jaringan irigasi yang terjadi. Beberapa hal yang kurang diperhatikan oleh pemerintah antara lain kurangnya pemasangan papan larangan dan papan peringatan disekitar bangunan irigasi yang terjal dan berbahaya. Pemerintah diharapkan lebih sering mengecek dan melakukan perawatan serta perbaikan di beberapa titik bangunan irigasi dalam rangka mempertahankan kondisi jaringan yang dilaksanakan secara terus menerus dengan rutin memberikan minyak pelumas pada bagian pintu, rutin membersihkan saluran dan bangunan dari tanaman liar, semak-semak, sampah dan kotoran serta rutin melakukan pembuangan endapan lumpur di bangunan ukur, rutin melakukan perbaikan pada bagian saluran yang rusak.

Pada kegiatan penanggulangan darurat bangunan irigasi yang rusak karena bencana alam, pemerintah diharapkan berperan serta aktif. Penanggulangan kerusakan bisa memanfaatkan bahan yang tersedia di dinas pengolaan irigasi atau yang tersedia di masyarakat, seperti kawat, bronjong, pasir, batu, karung. Selanjutnya diajukan anggaran program rehabilitasi untuk penyempurnaan konstruksi secara permanen. 
Dalam kegiatan rehabilitasi jaringan irigasi pemerintah rutin melakukan koordinasi dengan instansi terkait mengenai rehabilitasi jaringan irigasi, menyusun petunjuk pelaksanaan rehabilitasi jaringan irigasi sebagai penjabaran dari pedoman teknis, yang disesuaikan dengan kondisi setempat, dan rutin melaksanakan pembinaan dan pengendalian mulai dari persiapan, pelaksanaan monitoring dan evaluasi kegiatan rehabilitasi jaringan irigasi.

Dari hasil wawancara dan pengisisan kuisioner responden menyatakan peran serta pemerintah dianggap perlu ditingkatkan agar pengelolaan jaringan irigasi pada Daerah Irigasi Tiyingtali di Kabupaten Buleleng dapat berjalan secara optimal terutama dari segi pemeliharaan bangunan irigasi serta bangunan pelengkapnya sehingga kerusakan yang terjadi dapat diminimalkan. Selain itu pemerintah juga diharapkan sering melakukan sosialisasi atau penyuluhan kepada Subak mengenai pentingnya partisipasi Subak dalam pengelolaan jaringan irigasi tersebut. Pemerintah juga diharapkan rutin melakukan pelatihan kepada petugas yang bekerja di lapangan sebagai bentuk upaya yang dapat dilakukan untuk meningkatkan peran serta pemerintah dalam pengelolaan jaringan irigasi.

\section{ii. Peran Serta Subak}

Dari hasil analisa yang telah dilakukan dapat diketahui bahwa peran serta Subak berpengaruh secara signifikan baik secara simultan maupun parsial terhadap kegiatan pengelolaan jaringan irigasi pada Daerah Irigasi Tiyingtali di Kabupaten Buleleng. Dari hasil analisa dalam ujii F yang dilakukan dapat diketahui bahwa Fhitung $=10,961$ dan nilai Ftabel dengan tingkat keyakinan 95\% dan $\alpha=0,05$ derajat bebas $(\mathrm{df})=$ $(\mathrm{k}-1) ;(\mathrm{n}-\mathrm{k})=(2 ; 55)$ adalah sebesar 3,26 . Oleh karena $\mathrm{F}_{\text {hitung }}$ lebih besar daripada $\mathrm{F}_{\text {tabel }}$ dengan nilai signifikasi $0,000<0,05$ maka variabel peran serta Pemerintah dan peran serta Subak secara bersama-sama berpengaruh secara simultan dan signifikan terhadap pengelolaan jaringan irigasi pada Daerah Irigasi Tiyingtali di Kabupaten Buleleng. Untuk hasil uji $t$ didapat nilai $t_{\text {hitung }}(4,029)>t_{\text {tabel }}(1,673)$. Hal ini menunjukkan bahwa Subak berperan serta positif dan signifikan dalam pengelolaan jaringan irigasi pada Daerah Irigasi Tiyingtali di Kabupaten Buleleng.

Berdasarkan hasil analisa tingkat peran serta Subak memiliki nilai Standardized Coefficient Beta sebesar 0,496. Nilai tingkat peran serta Subak dinilai lebih tinggi dari tingkat peran serta Pemerintah yang memiliki nilai Standardized Coefficient Beta sebesar 0,109. Hasil ini menunjukkan bahwa responden menilai tingkat peran serta Subak lebih tinggi daripada tingkat peran serta Pemerintah dalam pengelolaan jaringan irigasi pada Daerah Irigasi Tiyingtali di Kabupaten Buleleng.

Subak memilik peranan yang sangat penting dalam kegiatan pengelolaan jaringan irigasi. Pengelolaan jaringan irigasi merupakan kegiatan yang meliputi operasi jaringan irigasi, pemeliharaan jaringan irigasi dan rehabilitasi jaringan irigasi pada Daerah Irigasi. Subak berperan serta dalam kegiatan pengumpulan data dengan memberikan informasi mengenai data - data yang diperlukan seperti data luas areal pertanian, jenis tanaman, luas panen dan kerusakan tanaman. Dalam kegiatan perencanaan pengelolaan jaringan irigasi, Subak berperan serta dalam mendiskusikan komoditas yang akan ditanam bersama dengan kelompok petani lain dan menentukan usulan rencana tata tanam yang diinginkan secara musyawarah bersama anggotanya berdasarkan hak guna air yang diberikan.

Dalam kegiatan operasi jaringan irigasi Subak rutin melakukan diskusi komoditas yang akan ditanam bersama dengan petani lainnya. Subak turut berperan serta memberikan masukan mengenai perubahan tata tanam, pola tanam, jadwal tanam serta jadwal pemberian/pembagian air apabila terjadi perubahan ketersediaan air pada sumber air. Dalam hal pengoperasian bangunan pengatur irigasi Subak berperan serta dalam membantu melaksanakan pekerjaan operasi seperti membuka, menutup, dan memberikan pelumasan pintu air serta menerima alokasi air irigasi serta rutin melakukan penyampaian laporan hasil pengamatan dilapangan seperti terjadi pengambilan air secara tidak resmi dan melaporkan kerusakan-kerusakan yang terjadi pada bangunan irigasi.

Subak juga diharapkan meningkatakan peran sertanya dalam pelaksanaan kegiatan konstruksi rehabilitasi secara swakelola dengan bekerja sama dengan pemerintah ataupun dalam bentuk tenaga, bahan, atau biaya sesuai dengan kemampuannya pada bangunan penangkap air, seperti bendung sederhana dan pengambilan bebas lainnya serta bangunan pelengkapnya.

Berdasarkan hasil pengambilan data melalui kuisioner untuk indikator pengumpulan data, perencanaan pengelolaan jaringan irigasi serta pelaksanaan pengelolaan jaringan irigasi sebagian besar responden menyatakan Subak telah ikut berperan serta dengan baik terutama dalam kegiatan pengumpulan data seperti pengumpulan data pola tanam, dan data luas tanam. Sebagian besar responden juga menyatakan Subak sudah turut berperan serta dalam kegiatan perencanaan operasi jaringan irigasi dimana Subak selalu hadir dalam setiap kegiatan yang berkaitan tentang perencanaan bangunan irigasi. Subak juga sering kali memberikan masukan untuk peningkatan kinerja jaringan irigasi serta masukan mengenai ketersediaan air yang mungkin bisa digunakan untuk pertanian. Namun tidak sedikit juga responden yang mengharapkan peningkatan peran serta Subak dalam pengelolaan jaringan irigasi. Berdasarkan hasil 
wawancara yang dilakukan terutama dari pihak pemerintah mengharapkan adanya peningkatan peran serta Subak dalam melakukan pendataan atas bangunan-bangunan irigasi yang kurang berfungsi dengan baik akibat adanya kerusakan dan kebocoran dibeberapa titik sehingga pemerintah dapat segera menangani permasalahan tersebut. Selain itu pemerintah juga mengharapkan Subak meningkatkan peran sertanya dalam memonitoring dan mengevaluasi adanya pengambilan air irigasi secara tidak resmi serta konflik air dan kerusakan - kerusakan bangunan, saluran dan pintu air.

Dari hasil wawancara yang dilakukan peningkatan peran serta Subak dalam pengelolaan jaringan irigasi dianggap perlu ditingkatkan terutama dari segi pemeliharaan bangunan irigasi terutama pada bangunan bagi di saluran sekunder dan saluran tersier. Peningkatann peran serta tersebut dapat berupa pembersihan saluran dari sampah dan kotoran lainnya sehingga dapat mengoptimalkan fungsi dari saluran irigasi tersebut. Dalam kegiatan pengamanan dan pencegahan kerusakan jaringan irigasi, pemerintah mengharapkan Subak lebih meningkatkan peran serta dalam membantu melakukan penelusuran untuk mengidentifikasi kerusakan-kerusakan yang terjadi pada bangunan irigasi dan menyampaikan usulan rencana perbaikan dan skala prioritas bersama dengan petugas pengelola irigasi. Selain itu dalam kegiatan pemeliharaan jaringan irigasi Subak diharapkan juga untuk berperan serta dalam melakukan pengawasan atas pelaksanaan pemeliharaan jaringan irigasi primer dan sekunder dalam bentuk penyampaian laporan penyimpangan pelaksanaan kepada dinas atau pengelola irigasi. Subak mengharapkan adanya bantuan rutin dari pemerintah berupa dana perbaikan agar dapat mengoptimalkan fungsi kinerja bangunan irigasi.

\section{KESIMPULAN DAN SARAN}

Kesimpulan yang dapat diambil dari hasil penelitian dan analisa yang dilakukan ini adalah sebagai berikut:

a. Peran serta Pemangku Kepentingan baik dari Pemerintah dan Subak adalah sebesar 68,3\% dalam pengelolaan jaringan irigasi pada Daerah Irigasi Tiyingtali di Kabupaten Buleleng. Sebesar 31,7\% sisanya dipengaruhi oleh faktor atau Pemangku Kepentingan lainnya yang tidak termasuk dalam pembahasan penelitian. Hal tersebut dapat dilihat dari hasil analisa tingkat peran serta Pemangku Kepentingan yang menunjukkan nilai adjusted $R$ squared sebesar 0,683 .

b. Dari hasil analisa dalam uji $\mathrm{F}$ yang dilakukan dapat diketahui bahwa nilai $\mathrm{F}_{\text {hitung }}=10,961$ dan nilai $\mathrm{F}_{\text {tabel }}$ dengan tingkat keyakinan $95 \%$ dan $\alpha=0,05$ derajat bebas $(\mathrm{df})=(\mathrm{k}-1) ;(\mathrm{n}-\mathrm{k})=(2 ; 55)$ adalah sebesar 3,26. Oleh

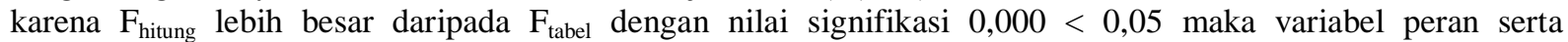
Pemerintah dan peran serta Subak secara bersama-sama berpengaruh secara simultan dan signifikan terhadap pengelolaan jaringan irigasi pada Daerah Irigasi Tiyingtali di Kabupaten Buleleng.

c. Untuk peran serta pemerintah hasil uji $t$ didapat nilai $t_{\text {hitung }}(1,924)>t_{\text {tabel }}(1,673)$. Hal ini menunjukkan bahwa Pemerintah berperan serta positif dan signifikan. Untuk peran serta Subak hasil uji t didapat nilai $t_{\text {hitung }}$ $(4,029)>t_{\text {tabel }}(1,673)$. Hal ini menunjukkan bahwa Subak berperan serta positif dan signifikan. Berdasarkan hasil uji tersebut dapat disimpulkan bahwa peran serta Pemerintah dan Subak secara parsial berpengaruh signifikan secara parsial terhadap pengelolaan jaringan irigasi pada Daerah Irigasi Tiyingtali di Kabupaten Buleleng.

Saran yang dapat diambil dari hasil penelitian dan analisa yang dilakukan ini adalah sebagai berikut:

a. Berdasarkan hasil analisis dapat diketahui Subak memiliki tingkat peran serta yang lebih tinggi daripada peran serta Pemerintah, sehingga Pemerintah disarankan untuk lebih meningkatkan peran sertanya terutama dalam pemeliharaan saluran irigasi dan juga rutin melakukan bimbingan teknis kepada Subak yang ada.

b. Untuk meningkatkan peran serta Pemerintah dalam pengelolaan jaringan perlu dilakukan penelusuran lapangan langsung bersama dengan petugas lapangan dan Subak untuk meninjau fungsi dan kinerja dari setiap bangunan irigasi yang ada pada jaringan irigasi pada Daerah Irigasi Tiyingtali di Kabupaten Buleleng.

c. Agar peran serta pemangku kepentingan dalam pengelolaan jaringan irigasi pada Daerah Irigasi Tiyingtali di Kabupaten Buleleng dapat ditingkatkan, perlu ditinjau pemangku kepentingan lain selain sektor pemerintah maupun Subak yang belum tercantum dalam penelitian.

\section{UCAPAN TERIMAKASIH}

Pertama-tama perkenankanlah penulis memanjatkan puji syukur ke hadapan Ida Sang Hyang Widhi Wasa/Tuhan Yang Maha Esa, karena hanya atas asung kerta wara nugraha-Nya, penelitian ini dapat diselesaikan. Pada kesempatan ini penulis mengucapkan terima kasih kepada keluarga, teman dan rekan sejawat yang selalu mendukung penulis dalam melaksanakan penelitian. Terimakasih juga penulis ucapkan kepada semua pihak dari pemerintah dan dari Subak Tiyingtali yang sudah bersedia meluangkan waktunya menjadi responden pada penelitian ini. 


\section{DAFTAR PUSTAKA}

Anonim, 2013. Pengelolaan Jaringan Irigasi dan Permasalahannya.(serial online).April Available from URL: https://www.scribd.com/doc/135797735/Pengelolaan-Jaringan-Irigasi-Permasalahnnya.

Departemen Pekerjaan Umum dan Perumahan Rakyat, 2014. Keputusan Menteri Pekerjaan Umum dan Perumahan Rakyat Nomor: 293/KPTS/M/2014 tentang Penetapan Status Daerah Irigasi yang Pengelolaannya Menjadi Wewenang dan Tanggung Jawab Pemerintah, Pemerintah Provinsi, dan Pemerintah Kabupaten/Kota. Jakarta.

Departemen Pekerjaan Umum dan Perumahan Rakyat, 2015. Peraturan Menteri Pekerjaan Umum dan Perumahan Rakyat Nomor: 14/PRT/M/2015 tentang Kriteria dan Penetapan Status Daerah Irigasi. Jakarta.

Departemen Pekerjaan Umum dan Perumahan Rakyat, 2015. Peraturan Menteri Pekerjaan Umum dan Perumahan Rakyat Nomor: 30/PRT/M/2015 tentang Pengembangan dan Pengelolaan Sistem Irigasi. Jakarta.

Dinas Pekerjaan Umum dan Penataan Ruang Provinsi Bali. 2018. Laporan Akhir Tahun Seksi Pelaksanaan Bidang Sumber Daya Air.

Sekretaris Daerah Provinsi Bali,2012. Peraturan Daerah Provinsi Bali Nomor 9 Tahun 2012 Tentang Subak. Denpasar. 